\title{
Study on Genetic Effect of Yield and Related Traits through Generation Mean Analysis in Wheat (Triticum aestivum L.)
}

\author{
Shivang Sharma* and Ajay Prakash Agrawal \\ Department of Genetics and Plant Breeding, BTC CARS, Bilaspur (C.G.), India \\ *Corresponding author
}

\section{Keywords}

Wheat, Joint scaling test, six parameter model, Gene effect

Article Info

Accepted:

18 May 2020

Available Online:

10 June 2020

\begin{abstract}
A B S T R A C T
The objective this study was to effect of gene effects for some agronomical traits (plant height, number of effective tillers per plant, number of spikelet per spike, number of seeds per plant, seed yield and biological yield) of Cross I CG1608 (HI 1544 x GW 2013-513) and Cross II CG 1639 (RAJ $4270 \times$ GW 366) The experimental material comprising of six generations $\left(\mathrm{P}_{1}, \mathrm{P}_{2}, \mathrm{~F}_{1}, \mathrm{~F}_{2}, \mathrm{BC}_{1}\right.$ and $\mathrm{BC}_{2}$ ) of wheat crosses was planted during rabi 2018-19 in randomized block design of two replication under irrigated condition at All India Co-ordinated Wheat and Barley Improvement Project at B.T.C College of Agriculture and Research Station, Bilaspur, Chhattisgarh, India. The scaling test A, B, C and D scale in both the crosses which indicated the result that there is presence of one, two or all the three type non-allelic interaction or epistasis. When the significance of scaling test was observed for the characters than only the further analysis for gene action was done on six parameter model i.e., mean effect $(\mathrm{m})$, additive gene effect(d), dominance gene effect(h), additive epistasis(i), dominance epistasis (j), additive dominance epistasis(l), all the six parameter was found significant for the characters plant height, number of seeds per spike in both cross I (CG 1608) and cross II (CG 1639), whereas some characters like number of spikelets per spike, number of seeds per plant and biological yield was significant for all six parameters only in cross I (CG 1608). The duplicate type of gene action was showed by most of the characters in both the crosses.
\end{abstract}

\section{Introduction}

Wheat (Triticum aestivum L.) is crop of world significance. It can be grown in various environments. Wheat is the second maximum important cereal staple food crop ate up via almost 35 percent of worldwide population and gives 20 percent meals calories.

Wheat is also called the "King of all cereal's" emerging as the backbone of India's meals protection and represents the staple food for about one third of the sector's population.
After processing it is used for making bread, biscuits, cookies, chapatti etc. complete wheat grain contains crude protein $(13.21 \%)$, fats (2.10\%), minerals (2.10\%), fiber $(2.30 \%)$, different carbohydrate $(78.10 \%)$ and water (12\%) (Fraley, 2003).

Industrially, it is used in preparation of starch, gluten, malt, and distilled spirit and also wheat bran is rich in protein and used as valuable livestock feed. India is second highest in the wheat production, occupies a place of 30785.23 (thousand hectare) with a 
manufacturing of 98510.22 (thousand tones), with a median countrywide productiveness of $3200 \mathrm{~kg} /$ ha. (Anonymous 2016-17) Chhattisgarh occupies an area of 114.70 (thousand hectare) with manufacturing of 159.50 (thousand tones), with a median productivity of $1391 \mathrm{~kg} / \mathrm{ha}$. (Anonymous 2016-17).

Generation mean analysis (Mather and Jinks, 1982) presents information at the relative significance of common results of the genes (additive outcomes), dominance deviations and outcomes because of non-allelic genetic interactions in figuring out genotypic values of the people and therefore, suggest genotypic values of families and generations. Generations suggest evaluation is a simple however useful technique for estimating gene results for a polygenic trait, its finest merit lying within the capacity to estimate epistatic gene results together with additive $\mathrm{x}$ additive, dominance $\mathrm{x}$ dominance and additive $\mathrm{x}$ dominance effects.

This examine is completed to determine the capacity of morphological and physiological traits in terms of heritability, genetic improve and form of gene movement prevailing in wheat the usage of six generations model i.e. $\mathrm{P}_{1}, \mathrm{P}_{2}, \mathrm{~F}_{1}, \mathrm{~F}_{2}, \mathrm{BC}_{1}$, and $\mathrm{BC}_{2}$ in two wheat crosses.

\section{Materials and Methods}

\section{Materials used for generation mean analysis study}

\section{Cross-1(CG 1608)}

1. HI 1544

2. GW 2013-513

3. HI $1544 \mathrm{X}$ GW 2013-513 (CG 1608)- $\mathrm{F}_{1}$

4. CG 1608 X GW 2013-513 - $\mathrm{BC}_{1}$

5. CG 1608 X HI $1544-\mathrm{BC}_{2}$

6. $\mathrm{F}_{1}$ when generation advanced $-\mathrm{F}_{2}$

\section{Cross-2 (CG 1639)}
1. Raj 4270
$-\mathrm{P}_{1}$
2. GW 366
$-\mathrm{P}_{2}$
3. Raj 4270 X GW 366 (CG 1639) - $F_{1}$
4. CG 1639 X Raj 4270
$-\mathrm{BC}_{1}$
5. CG 1639 X GW 366
$-\mathrm{BC}_{2}$
6. $\mathrm{F}_{1}$ when generation advanced $-\mathrm{F}_{2}$

Raising of $F_{1}$ and making backcrosses - In second crop season rabi 2017-18. F $_{1}$ plants of each cross were raised up, some of the $F_{1}$ plants were used to attempt backcrossed with $\mathrm{P}_{1}$ and $\mathrm{P}_{2}$ to obtain $\mathrm{BC}_{1}$ and $\mathrm{BC}_{2}$ populations. Some $F_{1}$ plants were selfed to obtain $F_{2}$ seed. Some $F_{1}$ seed obtained in the first year was saved to use evaluation trial during third crop season.

Evaluation of material - In the third crop season rabi 2018-19. Six populations viz. parent $\left(\mathrm{P}_{1}, \mathrm{P}_{2}\right)$, hybrid $\left(\mathrm{F}_{1}, \mathrm{~F}_{2}\right)$, and backcross $\left(\mathrm{BC}_{1}, \mathrm{BC}_{2}\right)$ are grown in replicated field trial as $\mathrm{P}_{1}, \mathrm{P}_{2}, \mathrm{~F}_{1}, \mathrm{BC}_{1}, \mathrm{BC}_{2}$ in 2 line each respectively whereas $\mathrm{F}_{2}$ as 30 lines, and observation is recorded on various quantitative character.

\section{Scaling tests}

Scaling test as describe by Hayman and Mather (1955) was used to check the adequacy of the additive - dominance model for different characters in two crosses. The adequacy to scale most satisfies two combinations viz., additivity of gene effects and independence of heritable components from non-heritable ones.

The type of epistasis was revealed by the significance of specific scale as given below:

The significance of $\mathrm{A}$ and $\mathrm{B}$ scales indicates the presence of all the three types of allelic gene interactions viz., additive $x$ additive (i), additive $x$ dominance $(j)$ and dominance $\mathrm{x}$ dominance (I). 
The significance of $\mathrm{C}$ scale suggested dominance $\mathrm{x}$ dominance (I) type of non-allelic gene interaction.

The significance $\mathrm{D}$ scale reveals additive $\mathrm{x}$ additive (i) type of gene interaction and significance of both $\mathrm{C}$ and $\mathrm{D}$ scales indicates additive $\mathrm{x}$ additive (i) and dominance $\mathrm{x}$ dominance (1) type of gene interactions.

\section{Joint scaling test}

In the Cavalli s (1952) joint scaling test parameters $\mathrm{m}, \mathrm{d}$, and $\mathrm{h}$ are estimated from the observed means of three or more generations. Estimates of these parameters are then used to calculate expected means which are then compared with observed means.

\section{The chi-square test for goodness of fit}

For testing the agreement of observed frequencies with those expected upon a given hypothesis, the chi $-\operatorname{square}\left(\mathrm{X}^{2}\right)$ test for goodness of fit as described by pearson (1899) was used

$\mathrm{X}^{2}=\mathrm{i}=\sum\left(\mathrm{O}_{\mathrm{i}}-\mathrm{E}_{\mathrm{i}}\right)^{2} / \mathrm{E}_{\mathrm{i}}$

Whereas,

$\mathrm{O}_{\mathrm{i}}=$ observed frequency of $\mathrm{i}^{\text {th }}$ class

$E_{i}=$ expected frequency of $i^{\text {th }}$ class

For testing the significance, the chi-square tabulated was seen at (n-1)d.f.

\section{Estimation of gene effect}

The mean values over replication are used for the estimation of the gene effects. Owing to presence of six generations in each cross, Hayman's (1958) six parameter model was followed to estimate gene effects including epistasis interactions.
The six parameter model was first suggested by Hayman's (1958) for estimation of various genetic components from the generation means. This method is used when non-allelic interactions are present. The analysis of this model is based on six generations viz., $\mathrm{P}_{1}, \mathrm{P}_{2}$, $\mathrm{F}_{1}, \mathrm{~F}_{2}$,

$\mathrm{BC}_{1}$ and $\mathrm{BC}_{2}$ and six parameters are obtained. These parameters are mean $(\mathrm{m})$, additive gene effect (d), dominance gene effects (h) and three types of non-allelic gene interactions viz, additive $\mathrm{x}$ additive (i), additive $\mathrm{x}$ dominance (j) and dominance $x$ dominance (l)

In this model various gene effect and variances are estimated as follow.

$\mathrm{m}=$ mean effect $=\overline{\mathrm{F}} 2$

$\mathrm{d}=$ additive effects $=\overline{\mathrm{B}} 1-\overline{\mathrm{B}} 2$

$\mathrm{h}=$ dominance effect

$=\overline{\mathrm{F}} 1-4 \overline{\mathrm{F}} 2-1 / 2 \overline{\mathrm{P}} 1-\quad 1 / 2 \overline{\mathrm{P}} 2+2 \overline{\mathrm{B}} 1+2 \overline{\mathrm{B}}$ 2

$\mathrm{i}=$ additive $\mathrm{x}$ additive gene interaction

$=2 \overline{\mathrm{B}} 1+2 \overline{\mathrm{B}} 2-4 \overline{\mathrm{F}} 2$

$\mathrm{j}=$ additive $\mathrm{x}$ dominance gene interaction

$=\overline{\mathrm{B}} 1-1 / 2 \overline{\mathrm{P}} 1-\overline{\mathrm{B}} 2+1 / 2 \overline{\mathrm{P}} 2$

$1=$ dominance $\mathrm{x}$ dominance gene interaction

$=\overline{\mathrm{P}} 1+\overline{\mathrm{P}} 2+2 \overline{\mathrm{F}} 1+4 \overline{\mathrm{F}} 2-4 \overline{\mathrm{B}} 1-4 \overline{\mathrm{B}} 2$

Where,

$\overline{\mathrm{P}} 1, \overline{\mathrm{P}} 2, \overline{\mathrm{F}} 1, \overline{\mathrm{F}} 2, \overline{\mathrm{B}} 1 \& \overline{\mathrm{B}} \quad 2$ are the mean value over replication for the character. And

$\mathrm{BC}_{1}$ and $\mathrm{BC}_{2}$ are $\mathrm{F}_{1}$ crossed with $\mathrm{P}_{1}$, and $\mathrm{F}_{1}$ crossed with $\mathrm{P}_{2}$, respectively.

\section{Results and Discussion}

Significance of scaling test is an indication of the presence of gene interaction but 
conformation and estimation of components including different gene interaction further analysis is needed. Hayman (1958) has developed methods for estimating additive, dominance and epistasis parameters based on component of mean of different generation. Accordingly, estimates of different gene effect and their interaction were worked out for the two crosses. The estimated mean effect (m) parameter, which reflects the contribution due to overall mean plus the locus effects and interaction of the fixed loci, were found highly significant for all the traits in the two crosses. The variation among the mean of different generations in all the characters studied necessitated the estimation of additive dominance and epistatic interaction.

\section{Plant height}

All the four scaling test were significant $\mathrm{A}\left(25.70^{* *}\right), \quad \mathrm{B}\left(-7,65^{* *}\right), \mathrm{C}\left(6.50^{* *}\right)$, and $\mathrm{D}\left(5.78^{* *}\right)$ in the cross I (HI $1544 \mathrm{X} \mathrm{GW}$ 2013-513) and A (-7.61**), B (-28.50**), C ($\left.13.60^{* *}\right)$ and $\mathrm{D}\left(-11.03^{* *}\right)$ in cross II (RAJ $4270 \mathrm{X} \mathrm{GW} 366$ ). And the chi-square were significant in joint scaling test for cross II (RAJ 4270 X GW 366) [553.8**]. Which indicate the inadequacy of additive dominance model. In the cross I (HI 1544 X GW 2013-513) [-17.87**] and cross II (RAJ $4270 \mathrm{X} \mathrm{GW} 366)$ [-8.32**]. The mean gene effect $(\mathrm{m})$ was positively significant found in cross I (HI 1544 X GW 2013-513) [87.23**] and cross II (RAJ $4270 \quad X \quad$ GW 366) [83.83**], the additive gene effect (d) was found negatively significant and the dominance gene $(h)$ effect was significant in both the crosses, cross I (HI $1544 \mathrm{X} \mathrm{GW}$ 2013-513)[2.55**] and cross II (RAJ $4270 \mathrm{X}$ GW 366) [9.31**], the additive $X$ additive (i) was found negatively significant for cross I (HI 1544X GW 2013-513)[-11.5**] and positively significant for cross II(RAJ $4270 \mathrm{X}$ GW 366)[22.06**], the additive $\mathrm{x}$ dominance (j) gene interaction was negatively significant in cross I (HI $1544 \mathrm{X}$ GW 2013-513)[$33.35^{* *}$ ]and in cross II (RAJ $4270 \mathrm{X}$ GW $366)\left[-20.44^{* *}\right]$. And dominance $\mathrm{x}$ dominance (1) gene effect was found positively significant in cross I (HI 1544 X GW 2013$513)[29.60 * *]$ and negatively significant is cross II (RAJ $4270 \mathrm{X}$ GW 366)[-57.72**]. The complementary epistasis was observed in cross I (HI 1544X GW 2013-513) and duplicate epistasis was observed in cross II (RAJ 4270 X GW 366). The above stated statements for scaling test and joint scaling test were found in accordance with Kumar et al., (2017), Ninghot et al., (2016). The above stated result for the mean effect $(\mathrm{m})$ additive gene effect (d), the dominance gene effect(h), the additive $X$ additive gene $\operatorname{effect}(\mathrm{h})$, the additive $\mathrm{X}$ dominance gene effect was satisfied with the work done by Mahapara et al., (2017) and the dominance $\mathrm{X}$ dominance gene effect was accordance with the work done by Khattab et al., (2010).

\section{Number of spikelets per spike}

The four scaling test was observed significant is $\mathrm{A}\left(2.50^{* *}\right), \mathrm{B}\left(-4.20^{* *}\right), \mathrm{C}\left(3.0^{* *}\right)$ and $\mathrm{D}(-$ $\left.2.35^{* *}\right)$ scale and chi-square in joint scaling test was also found significant in both the cross I (HI 1544 X GW 2013-513) [18.81**] and in cross II(RAJ $4270 \mathrm{X} \mathrm{GW} 366)$ the four scaling test $\mathrm{A}(8.00 * *), \mathrm{B}(5.2 * *), \mathrm{C}(4.60 * *)$, and $\mathrm{D}(4.30 * *)$ and chi-square in joint scaling test was also found significant [116.84**] which indicate the inadequacy of additive dominance model. The mean gene effect (m) was positively significant found in cross I (HI 1544 X GW 2013-513) [15.13**] and cross II (RAJ 4270 X GW 366) [14.65**], in cross I (HI 1544 X GW 2013-513) [-4.0**] the additive gene effect (d) was found negatively significant. The dominance gene effect (h) was observed positively significant in cross I (HI 1544 X GW 2013-513) [6.55**] and negatively significant in cross II (RAJ $4270 \mathrm{X}$ GW 366) $[-6.60 * *]$. The additive $\mathrm{x}$ additive gene effect (i) was observed positively 
significant in cross I(HI 1544X GW 2013513)[4.70**] and negatively significant in cross II(RAJ $4270 \mathrm{X}$ GW 366)[-8.60**].The additive $X$ dominance gene effect (j) was observed negatively significant for cross $\mathrm{I}(\mathrm{HI}$ 1544 X GW 2013-513)[-2.80**] and in cross $\mathrm{II}(\mathrm{RAJ} \quad 4270 \mathrm{X}$ GW 366)[5.70**], the dominance $\mathrm{x}$ dominance (1) effect was observed negatively significant in cross I (HI $1544 \mathrm{X}$ GW 2013-513)[-6.4**] and positively significant in cross II(RAJ $4270 \mathrm{X}$ GW 366)[21.80**]. Duplicate gene action was found in both the crosses. the above stated result for the mean(m) gene effect, additive gene effect (d), the additive $\mathrm{X}$ additive gene effect(i) was accordance with Mahpara et al., (2017), and dominance X dominance (1) was satisfied with the work done by Khattab et al., (2010).

\section{Number of seeds per spike}

The three scaling test viz., $\mathrm{A}\left(7.10^{* *}\right)$, $\mathrm{C}\left(22.40^{* *}\right)$ and $\mathrm{D}\left(-6.95^{* *}\right)$ scale was found to be significant in cross I (HI $1544 \mathrm{X} \mathrm{GW}$ 2013-513) and cross II ( RAJ $4270 \mathrm{X} \mathrm{GW}$ $366), \mathrm{A}(5.60 * *), \mathrm{B}(21.10 * *), \mathrm{C}(-8.30 * *)$ and chi - square in joint scaling test was also found significant in both the cross I (HI 1544 X GW 2013-513)[24.4**] and cross II( RAJ $4270 \mathrm{X} \mathrm{GW} 366)\left[16.1^{* *}\right]$. Which indicate the inadequacy of additive dominance model.

The mean gene effect (m) was positively significant found in cross I (HI 1544 X GW 2013-513) [34.98**] and cross II (RAJ 4270 $X$ GW 366) [33.05**], the additive gene effect (d) was found negatively significant for cross I (HI 1544 X GW 2013-513)[-1.90*] and cross II(RAJ $4270 \quad X \quad$ GW 366$)[-$ $\left.2.80^{* *}\right]$.The dominance gene effect $(\mathrm{h})$ was observed positively significant in cross I (HI $1544 \mathrm{X} \mathrm{GW} 2013-513)\left[20.35^{* *}\right]$ and in cross II(RAJ $4270 \quad X \quad$ GW 366)[28.55**].The additive $\mathrm{x}$ additive gene effect (i) was observed positively significant in cross I (HI $1544 \mathrm{X}$ GW 2013-513)[13.90**] and in cross
II(RAJ $4270 \quad X \quad$ GW 366)[16.60**].The additive $x$ dominance gene effect (j) was observed negatively significant for cross $\mathrm{I}(\mathrm{HI}$ 1544 X GW 2013-513)[-5.07**] and cross II ( RAJ $4270 \quad X \quad$ GW 366)[-6.70**], the dominance $\mathrm{x}$ dominance (l) effect was observed negatively significant in cross $\mathrm{I}(\mathrm{HI}$ 1544 X GW 2013-513)[-5.40**] and in cross II( RAJ $4270 \quad X \quad$ GW 366)[-12.10**]. Duplicate epistasis was found in both the crosses. The above stated statement for scaling test and joint scaling test were found in accordance with Said (2014), the above stated result for the mean gene effect $(\mathrm{m})$, additive gene effect (d), dominance gene effect ( $h$ ), the additive $X$ additive gene effect(i), additive $X$ dominance gene effect $(j)$, dominance $\mathrm{X}$ dominance gene effect (l) was accordance with the work done by Khattab et al., (2010) and Mahpara et al., (2017).

\section{Number of seeds per plant}

The four scaling test viz., $\mathrm{A}(32.70 * *)$, $\mathrm{B}\left(17.0^{* *}\right), \mathrm{C}\left(116.0^{* *}\right)$ and $\mathrm{D}\left(-33.15^{* *}\right)$ scale was to be significant in cross I (HI-1544X GW2013-513) and four scaling test was observed significant is $\mathrm{A}\left(15.10^{* *}\right)$, $\mathrm{B}(14.20 * *), \quad \mathrm{C}(72.10 * *)$ and $\mathrm{D}(-24.40 * *)$ scale in cross II(RAJ $4270 \mathrm{X}$ GW 366) and chi - square in joint scaling test was also found significant in both the cross I(HI 1544 X GW 2013-513)[100.38**] and cross II(RAJ 4270 X GW 366)[31.14**] which indicate the inadequacy of additive dominance model. In cross I (HI 1544 X GW 2013-513). The mean gene effect $(\mathrm{m})$ was positively significant found in cross I (HI 1544 X GW 2013-513) [144.83**] and cross II (RAJ $4270 \mathrm{X} \mathrm{GW}$ 366) $[155.70 * *]$, the additive gene effect (d) was found negatively significant $\left(-8.40^{* *}\right)$.

The dominance gene effect (h) was observed positively significant in cross I (HI $1544 \mathrm{X}$ GW 2013-513) [82.54**] and in cross II(RAJ 4270 X GW 366)[64.95**]. 
Table.1 Estimation of scaling test various traits in wheat Cross I (HI 1544 X GW 2013-513) and Cross II (RAJ 4270 X GW-366)

\begin{tabular}{|c|c|c|c|c|c|c|}
\hline Traits & Crosses & $\mathbf{A}$ & B & $\mathbf{C}$ & D & Suggested gene action \\
\hline \multirow[t]{2}{*}{ Plant height (cm) } & I & $25.70 * *$ & $-7.65 * *$ & $6.50 * *$ & $5.78 * *$ & Presence of all three type of interaction \\
\hline & II & $-7.61 * *$ & $-28.05 * *$ & $-13.60 * *$ & $-11.03 * *$ & Presence of all three type of interaction \\
\hline \multirow[t]{2}{*}{ Number of spikelets per spike } & I & $2.50 * *$ & $-4.20 * *$ & $3.00 * *$ & $-2.35^{*}$ & Presence of all three type of interaction \\
\hline & II & $8.008^{*}$ & $5.20 * *$ & $4.60 * *$ & $4.30 * *$ & Presence of all three type of interaction \\
\hline \multirow[t]{2}{*}{ Number of seeds per spike } & $\mathrm{I}$ & $7.10 * *$ & $1.40^{\mathrm{ns}}$ & $22.40 * *$ & $-6.95 * *$ & Presence of all three type of interaction \\
\hline & II & $5.60 * *$ & $-1.10^{\mathrm{ns}}$ & $21.10 * *$ & $-8.30 * *$ & Presence of all three type of interaction \\
\hline \multirow[t]{2}{*}{ Number of seeds per plant } & I & $32.70 * *$ & $17.00 * *$ & $116.00 * *$ & $-33.15 * *$ & Presence of all three type of interaction \\
\hline & II & $15.10 * *$ & $14.20 * *$ & $72.10 * *$ & $-21.40 * *$ & Presence of all three type of interaction \\
\hline \multirow[t]{2}{*}{ Seed yield per plant } & I & $2.59 * *$ & $1.44^{\mathrm{ns}}$ & $5.76 * *$ & $-0.86^{\mathrm{ns}}$ & Presence of all three type of interaction \\
\hline & II & $0.69^{\text {ns }}$ & $0.97^{\mathrm{ns}}$ & $4.00 * *$ & $-1.17^{\mathrm{ns}}$ & Presence of 1 type of gene interaction \\
\hline \multirow[t]{2}{*}{ Biological yield } & I & $4.18 * *$ & $-4.56 * *$ & $11.04 * *$ & $-5.71 * *$ & Presence of all three type of interaction \\
\hline & II & $3.47 * *$ & $7.90 * *$ & $10.19 * *$ & $0.59^{\mathrm{ns}}$ & Presence of all three type of interaction \\
\hline
\end{tabular}

$*$ and $* *$ indicate significance at $5 \%(1.68)$ and $1 \%(2.41)$ levels of significance respectively

Table.2 Genetic Parameters of various traits in wheat Cross I (HI 1544 X GW 2013-513) and Cross II (RAJ 4270 X GW-366)

\begin{tabular}{|c|c|c|c|c|c|c|c|c|}
\hline \multirow[b]{2}{*}{ Traits } & \multirow[b]{2}{*}{ Crosses } & \multicolumn{6}{|c|}{ Genetic parameters } & \multirow[b]{2}{*}{ Gene action } \\
\hline & & $\mathbf{m}$ & d & h & i & $\mathbf{j}$ & $\mathbf{l}$ & \\
\hline \multirow[t]{2}{*}{ Plant height (cm) } & I & $87.23 * *$ & $-17.87 * *$ & $2.55^{* *}$ & $-11.55^{* *}$ & $-33.35 * *$ & $29.60 * *$ & Complementary type of epistasis \\
\hline & II & $83.83 * *$ & $-8.32 * *$ & $9.31 * *$ & $22.06 * *$ & $-20.44 * *$ & $-57.72 * *$ & Duplicate type of epistasis \\
\hline \multirow[t]{2}{*}{ Number of spikelets per spike } & I & $15.13 * *$ & $-4.00 * *$ & $6.55 * *$ & $4.70 * *$ & $-6.70 * *$ & $-6.40 * *$ & Duplicate type of epistasis \\
\hline & II & $14.65 * *$ & $-1.20 \mathrm{~ns}$ & $-6.60 * *$ & $-8.60 \mathrm{~ns}$ & $-2.80 * *$ & $21.80 * *$ & Duplicate type of epistasis \\
\hline \multirow[t]{2}{*}{ Number of seeds per spike } & I & $34.98 * *$ & $-1.90 *$ & $20.35 * *$ & $13.90 * *$ & $-5.70 * *$ & $-5.40 * *$ & Duplicate type of epistasis \\
\hline & II & $33.05 * *$ & $-2.80 * *$ & $28.55 * *$ & $16.60 * *$ & $-6.70 * *$ & $-12.10 * *$ & Duplicate type of epistasis \\
\hline \multirow[t]{2}{*}{ Number of seeds per plant } & I & $144.83 * *$ & $-8.40 * *$ & $82.25 * *$ & $66.30 * *$ & $-15.70 * *$ & $-16.60 * *$ & Duplicate type of epistasis \\
\hline & II & $155.70 * *$ & $-1.00 \mathrm{~ns}$ & $64.95 * *$ & $42.80 * *$ & $-0.90 \mathrm{~ns}$ & $-13.50 * *$ & Duplicate type of epistasis \\
\hline \multirow[t]{2}{*}{ Seed yield per plant } & I & $6.40 * *$ & $-0.54 \mathrm{~ns}$ & $3.89 * *$ & $1.73^{*}$ & $-1.15 \mathrm{~ns}$ & $2.31 * *$ & Complementary type of epistasis \\
\hline & II & $7.00 * *$ & $-0.15 \mathrm{~ns}$ & $3.65 * *$ & $2.35 * *$ & $0.28 \mathrm{~ns}$ & $-0.69 \mathrm{~ns}$ & Duplicate type of epistasis \\
\hline \multirow[t]{2}{*}{ Biological yield } & I & $13.17 * *$ & $-4.09 * *$ & $15.13 * *$ & $11.42 * *$ & $-8.74 * *$ & $-11.79 * *$ & Duplicate type of epistasis \\
\hline & II & $16.48 * *$ & $1.87 *$ & $7.17 * *$ & $-1.19 \mathrm{~ns}$ & $4.43 * *$ & $12.56^{* *}$ & Complementary type of epistasis \\
\hline
\end{tabular}

$*$ and $* *$ indicate significance at $5 \%(1.68)$ and $1 \%(2.41)$ levels of significance, respectively 
Table.3 Estimation of scaling test various traits in wheat Cross I (HI 1544 X GW 2013-513) and Cross II (RAJ 4270 X GW-366)

\begin{tabular}{|c|c|c|c|c|c|c|}
\hline Traits & Crosses & $\mathbf{A}$ & B & $\mathbf{C}$ & $\mathbf{D}$ & Suggested gene action \\
\hline \multirow[t]{2}{*}{ Plant height (cm) } & I & $25.70^{* *}$ & $-7.65^{* *}$ & $6.50 * *$ & $5.78 * *$ & Presence of all three type of interaction \\
\hline & II & $-7.61 * *$ & $-28.05 * *$ & $-13.60 * *$ & $-11.03 * *$ & Presence of all three type of interaction \\
\hline \multirow[t]{2}{*}{ Number of spikelets per spike } & I & $2.50 * *$ & $-4.20 * *$ & $3.00 * *$ & $-2.35^{*}$ & Presence of all three type of interaction \\
\hline & II & $8.008^{*}$ & $5.20 * *$ & $4.60 * *$ & $4.30 * *$ & Presence of all three type of interaction \\
\hline \multirow[t]{2}{*}{ Number of seeds per spike } & I & $7.10 * *$ & $1.40^{\mathrm{ns}}$ & $22.40 * *$ & $-6.95 * *$ & Presence of all three type of interaction \\
\hline & II & $5.60 * *$ & $-1.10^{\mathrm{ns}}$ & $21.10 * *$ & $-8.30 * *$ & Presence of all three type of interaction \\
\hline \multirow[t]{2}{*}{ Number of seeds per plant } & I & $32.70 * *$ & $17.00 * *$ & $116.00 * *$ & $-33.15^{* *}$ & Presence of all three type of interaction \\
\hline & II & $15.10^{* *}$ & $14.20 * *$ & $72.10^{* *}$ & $-21.40 * *$ & Presence of all three type of interaction \\
\hline \multirow[t]{2}{*}{ Seed yield per plant } & I & $2.59 * *$ & $1.44^{\mathrm{ns}}$ & $5.76^{* *}$ & $-0.86^{\mathrm{ns}}$ & Presence of all three type of interaction \\
\hline & II & $0.69^{\mathrm{ns}}$ & $0.97^{\mathrm{ns}}$ & $4.00 * *$ & $-1.17^{\mathrm{ns}}$ & Presence of 1 type of gene interaction \\
\hline \multirow[t]{2}{*}{ Biological yield } & $\mathrm{I}$ & $4.18 * *$ & $-4.56^{* *}$ & $11.04 * *$ & $-5.71 * *$ & Presence of all three type of interaction \\
\hline & II & $3.47 * *$ & $7.90 * *$ & $10.19 * *$ & $0.59^{\text {ns }}$ & Presence of all three type of interaction \\
\hline
\end{tabular}

$*$ and $* *$ indicate significance at $5 \%(1.68)$ and $1 \%(2.41)$ levels of significance respectively

Table.4 Estimation of Joint scaling test various traits in wheat Cross I (HI 1544 X GW 2013-513) and Cross II (RAJ 4270 X GW-366)

\begin{tabular}{|c|c|c|c|c|c|}
\hline Traits & Crosses & m & d & h & $X^{2}$ value \\
\hline \multirow[b]{2}{*}{ Plant height $(\mathrm{cm})$} & I & 79.95 & 9.43 & 15.24 & $1.26 * *$ \\
\hline & II & 90.41 & 0.69 & -13.71 & $553.8 * *$ \\
\hline \multirow[t]{2}{*}{ Number of spikelets per spike } & I & 14.67 & 1.17 & 1.76 & $18.81 * *$ \\
\hline & II & 14.43 & 0 & 0.09 & $116.84 * *$ \\
\hline \multirow[t]{2}{*}{ Number of seeds per spike } & I & 37.13 & -0.98 & 5.71 & $24.43 * *$ \\
\hline & II & 32.23 & -0.44 & 11.21 & $16.1 * *$ \\
\hline \multirow[t]{2}{*}{ Number of seeds per plant } & I & 162.39 & 0.21 & 18.39 & $100.38 * *$ \\
\hline & II & 162.41 & 0.58 & 21.6 & $31.14 * *$ \\
\hline \multirow[t]{2}{*}{ Seed yield per plant } & I & 6.52 & 0.04 & 2.27 & $92.18 * *$ \\
\hline & II & 7.32 & 0.29 & 1.22 & $25.94 * *$ \\
\hline \multirow[t]{2}{*}{ Biological yield } & I & 14.2 & 0.48 & 2.99 & $96.86 * *$ \\
\hline & II & 13.96 & -0.05 & 7.72 & $40.14 * *$ \\
\hline
\end{tabular}

$*$ and ** indicate significance at $5 \%(1.68)$ and $1 \%(2.41)$ levels of significance, respectively 
The additive $\mathrm{x}$ additive gene effect (i) was observed positively significant in cross I (HI 1544 X GW 2013-513) [66.30**] and in cross II(RAJ $4270 \quad X \quad$ GW 366) [42.80**].The additive $\mathrm{x}$ dominance gene effect (j) was observed negatively significant for cross I (HI $1544 \mathrm{X}$ GW 2013-513)[-15.70**], the dominance $\mathrm{x}$ dominance (1) effect was observed negatively significant in cross $\mathrm{I}(\mathrm{HI}$ 1544 X GW 2013-513)[-16.60**] and in cross II( RAJ 4270 X GW 366)[-13.50**].

Duplicate epistasis was found in both the crosses. The above stated statement for scaling test and joint scaling test were found in accordance with Said (2014), the above stated result for the mean gene effect (m), additive gene effect (d), dominance gene effect ( $h$ ), the additive $X$ additive gene effect (i), additive $\mathrm{X}$ dominance gene effect(j), dominance $\mathrm{X}$ dominance gene effect (1) was accordance with the work done by Khattab et al., (2010) .

\section{Seed yield per plant}

The two scaling test viz., $\mathrm{A}(2.59 * *)$ and $\mathrm{C}\left(5.76^{* *}\right)$ scale was found significant in cross I (HI 1544 X GW 2013-513) and one scaling test was observed significant is $\mathrm{C}\left(4.0^{* *}\right)$, scale in cross II(RAJ $4270 \mathrm{X} \mathrm{GW}$ 366), and chi-square in joint scaling test was also found significant in both the cross I(HI $1544 \mathrm{X}$ GW 2013-513)[92.18] and cross II (RAJ 4270 X GW 366)[25.94]. Which indicate the inadequacy of additive dominance model. The mean gene effect (m) was positively significant found in cross I (HI 1544 X GW 2013-513) [6.40**] and cross II (RAJ $4270 \mathrm{X}$ GW 366) [7.00**], the dominance gene effect (h) was observed positively significant $(3.89 * *)$ cross I(HI 1544 $\mathrm{X}$ GW 2013-513) [3.89**], and in cross II(RAJ $4270 \quad X \quad$ GW 366)[3.65**]. The additive $\mathrm{x}$ additive gene effect (i) was observed found significant in cross I(HI 1544
X GW 2013-513)[1.73*] cross II(RAJ 4270 X GW 366)[2.35**] and the dominance $X$ dominance (l) interaction was found significant for cross I(HI 1544 X GW 2013513)[2.31**],Complementary epistasis was observed in cross I (HI 1544 X GW 2013513), where as Duplicate epistasis in cross II( RAJ 4270 X GW 366). The above stated statement for scaling test and joint scaling test were found in accordance with Said (2014), Ninghot et al., (2016), Kumar et al., (2017). , the above stated result for the mean gene effect (m), additive gene effect (d), dominance gene effect $(\mathrm{h})$, the additive $\mathrm{X}$ additive gene effect(i), additive $X$ dominance gene effect $(\mathrm{j})$, dominance $\mathrm{X}$ dominance gene effect (1) was accordance with the work done by Khattab et al., (2010), Mahapara et al., (2017) Mohamed et al., (2014).

\section{Plant height (cm)}

In cross I (HI $1544 \mathrm{X} \mathrm{GW} 2013-513)$ and cross II (RAJ $4270 \mathrm{X} \mathrm{GW}$ 366) four scaling test was found significant on A, B, C and D scale. The mean gene effect $(\mathrm{m})$, the additive gene effect $(d)$, the dominance gene effect $(h)$, the three interaction i.e., the additive epistasis (i), the additive dominance epistasis (j) and dominance epistasis (1) was also significant.

\section{Number of spikelets per spike}

In cross I (HI $1544 \mathrm{X} \mathrm{GW} 2013-513)$ and cross II (RAJ $4270 \mathrm{X}$ GW 366) two scaling test was found significant on $\mathrm{B}$ and $\mathrm{C}$ scale and joint scaling test was also found significant. The mean gene effect $(\mathrm{m})$, the dominance gene effect (h) and the three interaction i.e., the additive epistasis (i), the additive dominance epistasis (j) and dominance epistasis (1) was also significant.

\section{Number seeds per spike}

In cross I (HI $1544 \mathrm{X} \mathrm{GW} 2013-513)$ and 
cross II (RAJ 4270 X GW 366) three scaling test was found significant on A, C and D scale and joint scaling test was also found significant. The mean gene effect $(\mathrm{m})$, the additive gene effect $(\mathrm{d})$, the dominance gene effect $(\mathrm{h})$ and the three interaction i.e., the additive epistasis (i), the additive dominance epistasis( $\mathrm{j}$ ) and dominance epistasis (l) was also significant.

\section{Number of seeds per plant}

In cross I (HI $1544 \mathrm{X} \mathrm{GW} 2013-513)$ and cross II (RAJ 4270 X GW 366) four scaling test was found significant on $\mathrm{A}, \mathrm{B}, \mathrm{C}$ and $\mathrm{D}$ scale and joint scaling test was also found significant. The mean gene effect $(\mathrm{m})$, the dominance gene effect (h) and the two interactions i.e., the additive epistasis (i) and dominance epistasis (1) was also significant.

\section{Seed yield per plant}

Iin cross I (HI 1544 X GW 2013-513) and cross II (RAJ $4270 \mathrm{X}$ GW 366) one scaling test was found significant on $\mathrm{C}$ scale and joint scaling test was also found significant. The mean gene effect $(\mathrm{m})$, the dominance gene effect (h) and the one interaction i.e., the additive epistasis (i) was also significant.

\section{Biological yield}

In cross I (HI $1544 \mathrm{X}$ GW 2013-513) and cross II (RAJ 4270 X GW 366) three scaling test was found significant on A, B and C scale and joint scaling test was also found significant. The mean gene effect $(\mathrm{m})$, the additive gene effect $(\mathrm{d})$, the dominance gene effect (h) and the two interaction i.e., the additive epistasis (i) and dominance epistasis (1) was also significant.

Based on the result obtained following conclusion can be drawn. Since, different gene effect was responsible for the inheritance of the some characters in different crosses, specific handling of individual crosses for different character would be advantageous for the improvement of these characters. In general the characters like plant height, number of spikelet per spike, number of seeds per spike, number of seed per plant are control by additive gene effect can best be improved by adopting different type of selection methods but pedigree method for this crop is beneficial. Whereas the characters like seed yield, biological yield are control by non- additive gene effect of both additive and non- additive gene effect can successfully be improved by utilizing hybrid vigour or follow inter or biparental mating or cyclic method of breeding i.e., reciprocal recurrent selection.

\section{References}

Cavalli, L. L. 1952. An analysis of linkage in quantitative inheritance. Quantitative Inheritance, H. M. S. O., London.

Hayman B. I. and Mather K. 1955. The description of genetics interaction in continuous variation. Biometrics, 11: 69-82.

Hayman, B.I., 1958. The seperation of epistatic additive and dominance variation in generation means. Heredity 12; 371-390.

Khattab, S.A.M., R. M. Esmail and Abd ELRahman and M.F. AL-Ansary 2010. Genetical analysis of some quantitative traits in bread wheat (Triticum aestivum L.). New York Science Journal. 3(11).

Kumar, S., Kumar, A. and Kumar, J. 2017. Genetic analysis for heterotic traits in bread wheat (Triticum aestivum L.) using six parameters model. Electronic Journal of Plant Breeding, 8: 206-215.

Ninghot, C. J., Boratkar, M. V., Thawari, S. B. and Potdukhe, N. R. 2016. Generation mean analysis for yield and yield components in wheat (Triticum aestivum L.). International Journal of 
Genetics, 8: 204-206.

Pearson, K. 1899 On certain properties of the hypergeometrical series, and on the fitting of such series to observation polygons in the theory of chance. 47 : 236-246.

Said, Ala Ali.2014. Generation mean analysis in wheat (Triticum aestivum L.) under drought stress condition. Annala of Agriculture Science, 59 (2): 177-184.

Shazadi Mahpara., Syed Tahir Hussain., Javed Iqbal., Ijaj Rasool and Sahid Salman 2018. Analysis of generation means for some metric plant traits in two wheat (Triticum aestivum L.) hybrids. Pure and applied biology.

\section{How to cite this article:}

Shivang Sharma and Ajay Prakash Agrawal. 2020. Study on Genetic Effect of Yield and Related Traits through Generation Mean Analysis in Wheat (Triticum aestivum L.). Int.J.Curr.Microbiol.App.Sci. 9(06): 1546-1556. doi: https://doi.org/10.20546/ijcmas.2020.906.191 